challenge to their professional omnipotence. In her classic paper Menzies notes how the ward environment and its procedures may be set up to reinforce defences that protect the staff working there from excessive anxiety to the detriment of patients' care. ${ }^{3}$

Individual professionals will find it difficult to work closely with dying patients unless they acknowledge their own emotional response to death and dying. Defences that leave their patients isolated will not be dismantled unless there is adequate and appropriate support provided. Until it is recognised that this support needs to be an integral part of both training and the weekly routine of the ward, patients dying in hospitals will die alone.

N RAMSAY

Claybury Hospital

Woodford Bridge,

Woodford Green,

Essex IG8 8BY

1 Mills M, Davies HTO, Macrae WA. Care of patients dying in hospital. BMF 1994;309:583-6. (3 September.)

2 Ramsay N. Sitting close to death-a ward observation on palliative care unit. Group Anabysis (in press).

Menzies IEP. The functioning of social systems as a defence against anxiety. Human Relations 1960;13:95-121.

\section{Technology foresight}

EDITOR,-Richard Smith's interview with Sir Dai Rees draws attention to the technology foresight programme currently being run by the Office of Science and Technology and to its importance in determining the direction and future funding of medical research.' At the end of the interview Sir Dai states that the Medical Research Council has a portfolio of developments encompassing a range of biomedical and clinical sciences yet works with only a fairly narrow range of industries-pharmaceuticals and food. At least one other industrythe medical equipment industry-should have been mentioned in this context.

The contribution that the medical equipment industry makes to maintaining and improving the health and general quality of life of the British population is often overlooked and underrated. This is partly because the industry is dwarfed by the pharmaceutical and food industries and partly because it is composed of many small companies. Although the industry is generally profitable and maintains a net positive balance of trade, there is little slack to finance the development of the new, innovative products that are needed to maintain market position. The medical equipment industry needs to be revitalised if it is to take advantage of the anticipated outcomes of the technology foresight programme and so prevent the haemorrhage of British inventions to our competitors abroad. The development of mechanisms for achieving this will be an effective indicator of the success of the technology foresight programme.

PETER GREENAWAY Member, health and life sciences pane

Salisbury SP5 2AZ

1 Smith R. Developing foresight: an interview with Sir Dai Rees. BMF 1994;309:324-6. (30 July.)

\section{Use of fetal eggs for research}

EDITOR,-In commenting on the public response to a consultation document published by the Human Fertilisation and Embryology Authority, Luisa Dillner correctly reports that $83 \%$ of responses were against the use of fetal eggs for infertility treatment but then says that "more than half the responses were in favour of using fetal eggs for research." In fact, an overwhelming majority was opposed to the use of fetal eggs in research: only $7 \cdot 1 \%$ of the respondents were in favour and $58.1 \%$ said "No." Dillner might also have mentioned that only $10 \cdot 7 \%$ and $14.3 \%$ of the responses, respectively, were in favour of eggs from cadavers and live donors being used for research, while $29 \cdot 2 \%$ and $24 \%$, respectively, explicitly opposed this.

I am concerned that Dillner's inaccurate report may mislead readers about the strength of public feeling against these sinister developments. I am also concerned that the Human Fertilisation and Embryology Authority should "seek to increase the supply of eggs for embryo research" despite this massive vote against. Perhaps it will have cause to review this position in the light of the recommendation by the Council of Europe's steering committee on bioethics that "human embryos may not be created with the intention of conducting research on them," ${ }_{3}$ although, as the authority the Human Fertilisation and Embryology Act.

DAVID W EVANS

Cambridge CB3 9LN

Retired consultant card

1 Dillner L. Use of fetal eggs for infertility treatment is banned. $B M F$ 1994;309:289-90. (30 July.)

2 Human Fertilisation and Embryology Authority. Donated ovarian tissue in embryo research and assisted conception. London: HFEA, 1994.

3 Sheldon T. European experts produce draft on bioethics. $B M F$ 1994;309:221.

\section{Results of prescription event monitoring study of salmeterol}

EDITOR,-The prescription event monitoring study of salmeterol ${ }^{1}$ is now complete and has shown the number of deaths due to asthma in patients treated with the drug to be lower than that predicted. Last year Castle et al reported on 16787 patients treated with salmeterol for 16 weeks. ${ }^{2}$ In these patients 54 deaths from all causes occurred $(0.32 \%)$, including 12 from asthma $(0.07 \%)$. The prescription event monitoring study has identified 1022 deaths $(6.6 \%)$ in our cohort of 15407 patients treated with salmeterol and observed for at least one year. Seventy three $(7 \cdot 1 \%)$ of the deaths (table I) were due to asthma, but only 39 of the 73 patients were taking salmeterol in the last month of life.

Our population was not only elderly (table II) but much more severely ill than that studied by Castle et al. For example, 37 of the 39 patients who died of asthma and were taking salmeterol in the notes, this is currently permitted (in Britain) under last month of life were known to be receiving

TABLE II-Distribution of patients who died of asthma by age and sex. Figures are numbers (percentages)

\begin{tabular}{lccc}
\hline $\begin{array}{l}\text { Age } \\
\text { (years) }\end{array}$ & $\begin{array}{c}\text { Male } \\
\text { patients }\end{array}$ & $\begin{array}{c}\text { Female } \\
\text { patients }\end{array}$ & $\begin{array}{c}\text { All } \\
\text { patients }\end{array}$ \\
\hline$<21$ & 0 & 0 & 0 \\
$21-$ & $1(3)$ & $1(2)$ & $2(3)$ \\
$31-$ & $2(6)$ & $5(12)$ & $7(10)$ \\
$41-$ & $4(13)$ & $3(7)$ & $7(10)$ \\
$51-$ & $2(6)$ & $12(29)$ & $14(19)$ \\
$61-$ & $12(39)$ & $12(29)$ & $24(33)$ \\
$71-$ & $8(26)$ & $8(19)$ & $16(22)$ \\
$>80$ & $2(6)$ & $1(2)$ & $3(4)$ \\
\hline Total & 31 & 42 & 73 \\
\hline
\end{tabular}

Average (SD)

age $\quad 62.6(14 \cdot 6) \quad 59.0(14 \cdot 2) \quad 60.5(14 \cdot 4)$

regular inhaled corticosteroids or oral corticosteroids, or both, before death.

We conclude that the death rate for asthma in our study $(73 / 15407 ; 0.47 \%)$ was greater than that found by Castle et al $(12 / 16787 ; 0.07 \%)$ because our study was at least three times longer than theirs and our population was both older and more severely ill. Nevertheless, the death rate from asthma in our study was substantially lower than that predicted ${ }^{1}$ at the time of the report by Castle et al.

The overall death rate from asthma in the prescription event monitoring study reflects the age distribution of and severity of disease in the population that received salmeterol in the early years after its introduction. All of the deaths from respiratory causes in the study seemed on careful examination of the clinical records to have been due to natural causes, although in four of the 39 patients who took salmeterol in the last month of life there was a temporal relation between death and use of salmeterol; this relation does not, of course, define a causal association.

This study, which will be reported fully, elicited no evidence that salmeterol contributed to the deaths from asthma. One probable reason for the earlier overestimate of the number of deaths due to asthma that were likely to occur in this study ${ }^{1}$ is the assumption that they would be evenly distributed throughout the study. In fact, 39 of the 73 deaths occurred in the first seven months of the study, which lasted for 25 months overall.

RONALD D MANN

Drug Safety Research Unit,

Southampton SO13 1AA

1 Inman WHW. Bronchodilator treatment in asthma. $B M Y 1993$ 306:1610.

2 Castle W, Fuller R, Hall J, Palmer J. Serevent nationwide surveillance study: comparison of salmeterol with salbutamol in asthmatic patients who require regular bronchodilator treatment. BMf 1993;306:1034-7.

TABLE -Causes of death among 15407 patients treated with salmeterol

\begin{tabular}{|c|c|c|c|c|c|}
\hline \multirow[b]{2}{*}{ Cause of death } & \multirow{2}{*}{$\begin{array}{l}\text { Total } \\
\text { No }\end{array}$} & \multicolumn{4}{|c|}{ Time from first prescription (months) } \\
\hline & & $1-4$ & $5-8$ & $9-12$ & $>12$ \\
\hline \multicolumn{6}{|l|}{ Respiratory: } \\
\hline Asthma & 73 & 27 & 17 & 12 & 17 \\
\hline Chronic bronchitis & 18 & 6 & 4 & 5 & 3 \\
\hline Bronchopneumonia & 13 & 7 & 0 & 0 & 6 \\
\hline Chronic obstructive airways disease & 362 & 92 & 71 & 82 & 117 \\
\hline Emphysema & 32 & 11 & 8 & 8 & 5 \\
\hline Other & 29 & 10 & 6 & 6 & 7 \\
\hline \multicolumn{6}{|l|}{ Cardiovascular: } \\
\hline Aneurysm & 19 & 4 & 8 & 4 & 3 \\
\hline Cardiac failure & 17 & 5 & 4 & 6 & 2 \\
\hline Cerebrovascular accident & 35 & 8 & 9 & 4 & 14 \\
\hline Ischaemic heart disease & 177 & 48 & 34 & 35 & 60 \\
\hline Other & 37 & 6 & 3 & 11 & 17 \\
\hline \multicolumn{6}{|l|}{ Malignancy: } \\
\hline Carcinoma of the bronchus & 62 & 10 & 6 & 23 & 23 \\
\hline Other & 83 & 14 & 20 & 23 & 26 \\
\hline \multicolumn{6}{|l|}{ Gastrointestinal: } \\
\hline Peptic ulcer & 10 & 1 & 1 & 3 & 5 \\
\hline Other & 13 & 2 & 4 & 2 & 5 \\
\hline \multicolumn{6}{|l|}{ Other: } \\
\hline All other known causes & 28 & 7 & 4 & 7 & 10 \\
\hline Cause uncertain & 14 & 0 & 0 & 1 & 13 \\
\hline Total & 1022 & 258 & 199 & 232 & 333 \\
\hline
\end{tabular}

